\title{
Protected area entrance fees in Tanzania: The search for competitiveness and value for money
}

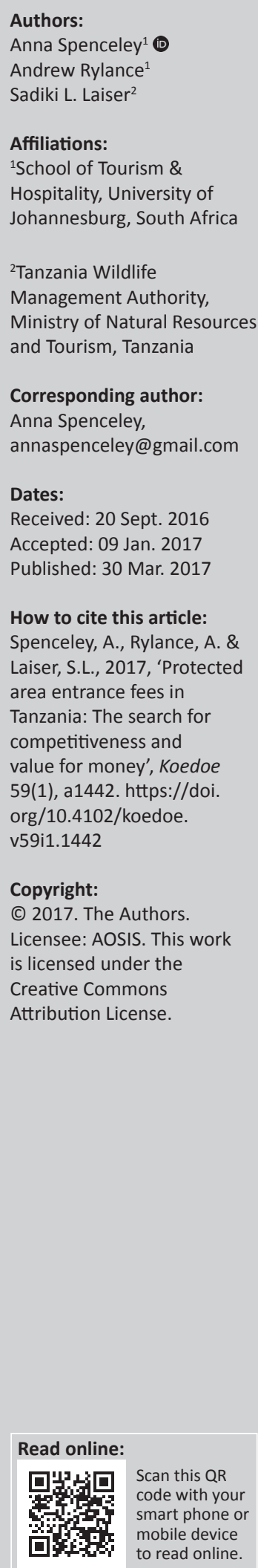

\begin{abstract}
User fees charged by Tanzania's Game Reserves (GR) and Wildlife Management Areas (WMAs) have not changed since 2008. Although previous research has been done on visitors' willingness-to-pay to enter national parks in Tanzania, none has been conducted on GRs and WMAs. This article assesses the entrance fees in GRs and WMAs, by comparing them with equivalent fees charged in Tanzania (at national parks and the Ngorongoro Crater) and also with regional protected areas in Botswana, Kenya, Namibia, South Africa and Zimbabwe. Based on 28 semi-structured interviews with key stakeholder institutions working on tourism and conservation and more than 50 online survey responses from Tanzanian tourism operators, the research reviews local opinion and issues relating to adjusting current entrance fees. The article considers that while one objective for generating revenue from entrance fees is for conservation management, it is difficult to establish appropriate fees where there are gaps in knowledge about existing levels of visitation, tourism revenue and associated management costs.
\end{abstract}

Conservation implications: This article has implications for protected area management practices, as it provides information on processes by which managers can review and revise entrance fee values.

\section{Introduction}

In some countries, there has been a determined shift from using government funding for the capital and operational needs of protected areas (PAs), towards charging fees for using services and facilities provided to visitors (e.g. Canada: Van Sickel \& Eagles 1998), tour operators and investors (e.g. South Africa: Spenceley 2004). In general, this shift has been caused by changes in government priorities for the use of public funds. User fees provide a mechanism for PA authorities to capture financial benefits of tourism that often accrue primarily to the private sector and which can be used to manage over-used or damaged areas (Kibira 2014) and also for the general management of a PA.

Approaches to establishing user fees in order to finance the management of PAs have been extensively documented. Perhaps one of the most extensively used approaches to researching entrance fees is contingent valuation approaches with willingness-to-pay (WTP) surveys (e.g. Asafu-Adjaye \& Tapsuwan 2008; Baral, Stern \& Bhattarai 2008; Barnes, Schier \& Van Rooy 1997; Bruner et al. 2015; Greiner \& Rolfe 2004; Kahn 2009; Kibira 2014; Mmopwlwa, Kgathi \& Molefhe 2007; Moran 1994; Reyisdottir, Song \& Agrusa 2008; Richer \& Christensen 1999; Schultz, Pinazzo \& Cifuentes 1998; Thur 2010; Walpole, Goodwin \& Ward 2001; Wang \& Jia 2012). Other approaches to establishing recreational value and fees include the Travel Cost Method (e.g. Chen et al 2004; Flemming \& Cook 2008; Herath \& Kennedy 2004; Turpie \& Joubert 2001) and price differentiation (e.g. Chase et al. 1998; Krug, Suich \& Haimbodi 2002).

More often than not, the WTP studies have found travellers are (1) willing to pay to visit PAs and (2) are willing to pay more than the established fee. For example, in Annapurna Conservation Area, Nepal, a WTP study found that on average visitors were willing to pay USD69, rather than the actual entrance fee of USD27 (Baral et al. 2008). Similarly, in Komodo National Park in Indonesia, an analysis of financial data and a WTP study with visitors found that although only $6.9 \%$ of park fees were recovered, tourists were willing to pay more than 10 times the current entrance fee (Walpole et al. 2001). WTP analysis was done by Dikgang and Muchapondwa (2016) found that the conservation fees in the Kgalagadi Transfrontier Park could be increased by up to $115 \%$ - which would almost double the current revenue. The pattern continues in marine PAs too: in Bonaire National Marine Park in the Netherlands Antilles, a survey found the average WTP for annual access ranged from USD61 to USD134, although the actual fee at that time was 
only USD10 (Thur 2010). Furthermore, it was predicted that doubling the USD10 user fee in Bonaire would have virtually no impact on visitation rates (Thur 2010).

In Tanzania, previous studies have been conducted on visitors WTP to visit national parks (e.g. Bruner et al. 2015; Kibira 2014). Based on interviews with 3263 visitors, Bruner et al. (2015) found that non-residents would be willing to pay substantially higher fees in the Serengeti National Park and that this would not seriously reduce the level of visitation. It was predicted that phasing-in a USD60 increase in the Serengeti conservation fee over several years could raise an additional USD14.8 million by 2020 (equivalent to increasing the park's revenue by 57\%). However, the study also established that price increases were park specific. Increased fees were not, for example, recommended at Kilimanjaro National Park (because of a perception that fees were already too high) and only modest increases be applied to Lake Manyara and Arusha National Parks to keep pace with inflation (e.g. USD5). Bruner et al.'s (2015) assessment supports earlier work by Kibira (2014) on the Serengeti. Kibira (2014) used contingent valuation to generate experimental data assessing the effects of changes in entrance fees to the Serengeti National Park. Kibira (2014) interviewed a random sample of 539 international tourists who visited the Serengeti National Park in 2013 and 2014 during the peak tourist season. The study found that visitation demand to the Serengeti is highly inelastic, which he attributes to the uniqueness of the park. Kibira (2014) suggests that Tanzanian National Parks (TANAPA) should be charging at least USD67 per day and up to USD185 if they want to maximise their revenues for park management. Although these studies exist for national parks, no study was identified that had reviewed pricing for Game Reserves (GRs) or Wildlife Management Areas (WMAs) in Tanzania.

Lindberg (2001) highlights that although there is no single 'correct' system for charging fees, often management decisions are only based on the objective of revenue generation. Sometimes the decisions are made with little or no consultation with affected stakeholders, notably the tourism industry and local communities. Lindberg (2001) warns that having narrow objectives and weak consultation can lead to unintended effects, such as sometimes a reversal of fee decisions by the PA authority, in response to stakeholder pressure.

\section{Protected areas in Tanzania}

Protected wildlife areas in Tanzania cover a total area of $246260.6 \mathrm{~km}^{2}$, covering $26.6 \%$ of the country's land area. These include 16 National Parks, 28 GRs, 44 Game-Controlled Areas (GCAs) and 38 WMAs. Historically, the Ministry of Natural Resources and Tourism (MNRT)'s Wildlife Division (WD) has been responsible for the management of wildlife resources outside TANAPA and the Ngorongoro Conservation Area Authority (NCAA). However, the Wildlife Conservation Act of 2009 directed the MNRT to establish the Tanzanian Wildlife Management Authority (TAWA), which would assume responsibility from the WD for wildlife management in the country's GRs, WMAs and GCAs. Following the official launch of TAWA in May 2014, its organisational framework was outlined in the Wildlife Conservation (The Tanzania Wildlife Management Authority) Establishment Order, 2014. The Order describes TAWA's proposed Directorate of Wildlife Utilisation, which would be responsible for activities including issuing permits and licenses in conservation areas, the development of tourism products, identification and diversification of economic potential from wildlife, and also for managing a business with the private sector. By contrast to the WD, TAWA is to be a self-financed autonomous organisation, with the mandate to hold back $80 \%$ of its revenues to be administered and used according to own demands and priorities.

It is important to highlight that financing this substantial PA system is extremely challenging. To illustrate, it is estimated that the financial requirements for both recurrent and capital budgets for the PA system costs USD49 million in 2016/2017 (MNRT 2015). Furthermore, predictions suggest that TAWA's financing gap will be in the region of USD12.6 million in the 2016/2017 financial year, with photographic tourism predicted to contribute USD5.2 million in revenue, trophy hunting and trade in wild animals to contribute USD18.4 million and USD12.5 million to be provided by government for salaries (MNRT 2015). A reorientation of the PA entrance and activity fees had been identified by the Government of Tanzania as an option for ensuring that their PAs are competitively priced relative to their competitors. Boosting revenues through tourism could help close the financing gap required for continued active conservation management. To support the MNRT in its process of developing TAWA, a study was commissioned by the Deutsche Gesellschaft für Internationale Zusammenarbeit (GIZ) programme 'Sustainable Management of Natural Resources' to evaluate the potential for non-consumptive tourism to generate revenue for conservation and management. A key focus of this study was to review potential changes in the fee structure of the PAs. Notably, the fees charged for GRs, GCAs and WMAs fees have remained unchanged since the Wildlife Conservation (Non-consumptive Wildlife Utilisation) Regulations, 2008. Just in terms of inflation, USD1 in 2008 had the same buying power as USD1.11 did in 2015 (CPI, undated). Therefore, this research presented a strategic opportunity to review prices of entrance and activity fees that would be competitive with other PAs in Tanzania and across southern Africa.

\section{Tourism in Tanzania}

The number of international arrivals in Tanzania has grown dramatically from about 500000 in 2000 to over 1.14 million visitors in 2014 (World Bank 2015). The tourism sector generates the bulk of export revenues for the country, typically exceeding minerals. It provides a reliable source of revenue to the government and generates direct employment to over 400000 people (World Bank 2015). In 2013 tourism was estimated to account for about $9.9 \%$ of 
GDP (equivalent to an amount of USD4 billion in direct and indirect contributions) (World Bank 2015). The majority of international arrivals are travelling for leisure, recreation and holiday $(81 \%)$, followed by visiting friends and relatives $(8 \%)$, business $(6 \%)$, transit $(2 \%)$ and other reasons $(3 \%)$ (MNRT 2015). The average length of stay in Tanzania in 2014 was 10 days, a duration that has been stable since 2012 (MNRT 2015). The average per night expenditure for a participant on a package tour is more than double that of a non-package tourist, at USD277 in 2014. However, there has been a dramatic decline in the level of expenditure by both types of travellers since 2012: by $27 \%$ for package tourists and 50\% for non-package tourists (MNRT 2015). The reasons for this decline are not known.

Visitation to national parks and to the Ngorongoro Crater is reported in the Tourism Statistical Bulletin, but visitation to GRs and WMAs is not. The most visited PAs in the country are the Ngorongoro Crater $(37.8 \%$ of recorded entries), followed by Serengeti National Park (24.9\% of entries), Tarangire (11.2\% of entries) and Arusha (10.8\% of entries) (adapted from MNRT Tourism Division 2015). It is estimated the $46 \%$ of international tourists experience a wildlife activity, compared to $26 \%$ with a beach holiday component and $11 \%$ doing hunting and fishing (SanchesPereira \& Muwanga 2015).

The purpose of this article is to describe the use of regional price benchmarking and market research with tourism stakeholders to investigate options to adapt fees charged at GRs and WMAs. This article focuses particularly on entrance fees and a discussion of other activity and service fees (i.e. camping fees, activity fees, commercial operator fees, concession fees, motor vehicle or boat or aircraft and balloon fees) can be found elsewhere (Spenceley 2016).

\section{Methodology}

A literature review was undertaken relating to previous research on tourism, conservation and PAs in Tanzania. Documents were obtained from donor and development agencies working in Tanzania, from stakeholders consulted and from an online search for academic research and grey literature. During this process, it was realised that no detailed information was available on existing levels of visitation, revenues accrued or the management costs of GRs or WMAs in Tanzania.

For the stakeholder consultation process on fees for GRs and WMAs, two approaches were used: a semistructured questionnaire used for face-to-face and telephone interviews and also a structured online survey tool. The semi-structured questionnaire tool was developed and implemented through a series of face-to-face and telephone interviews with representatives of 28 institutions working on tourism and conservation during October 2015. These included government departments (3 interviews), PA authorities (5 interviews), donor agencies (6 interviews), non-governmental organisations (2 interviews), private sector associations (3 interviews) and accommodation facilities in PAs (8 interviews). The stakeholders were selected through a combination of suggestions made by GIZ and a review of relevant institutions in Tanzania and referrals by interviewees (i.e. snowball sampling). The questionnaire included 37 questions that enquired about which PA systems were most competitive and comparable to Tanzania's, user fee options for GRs and WMAs and processes that should be applied to adjust them.

The online survey tool was developed to collate opinions on entrance fees within Tanzania's GRs and WMAs. The timeframe and resources available for the study meant that it was not feasible to interview visitors at each PA, and therefore, the survey was designed for tour operators working in PAs. Given their knowledge of their client base and the tourism sector as a whole, it was considered that their opinions provided a useful proxy for visitor preferences, though this is a limitation of the present study. This questionnaire simply presented the current prices charged by GRs and WMAs and asked respondents to indicate whether the price (which was shown) should remain the same or be changed to a different value. This approach was judged to be more practical than a dichotomous choice approach because such a diverse range of fees was listed in the Wildlife Conservation (Non-consumptive Wildlife Utilisation) Regulations, 2008 that needed to be investigated for GRs and WMAs separately (i.e. entry fees; commercial photography fees; camping fees; vehicle fees [e.g. cars, boats, rafts, canoes]; night drives; fishing; professional guide fees; aircraft and balloon fees). Providing an option for open responses (as by Greiner \& Rolfe 2004) ensured that the online questionnaire was not excessively long or complicated and improved the likelihood of a good response rate. The survey was distributed to operators by the country's three main tourism associations: Tanzanian Confederation of Tourism, the Hotels Association of Tanzania and the Tanzanian Association of Tour Operators to their members. The questionnaire was available online between 23 October and 08 November 2015, and 50 responses were received during that time.

For the regional price benchmarking process, information on current PA fees were collected from PA authority websites. These were converted into USD equivalent values for comparison. Prices were collated for PAs in Tanzania (i.e. national parks, the Ngorongoro Conservation Area, GRs and WMAs). Prices were also reviewed for a selection of southern African PA agencies in East and Southern Africa that have similar and competitive wildlife products to Tanzania, as suggested by stakeholders during the stakeholder consultation process (see above). These included national parks and GRs, but there was no publically available data identified for WMA-equivalent areas. The countries reviewed comprised Botswana, Kenya, Namibia, South Africa and Zimbabwe. In South Africa, information was also used by two provincial conservation agencies that manage GRs (i.e. Ezemvelo KwaZulu-Natal Wildlife and Cape Nature). 


\section{Results \\ National and regional benchmarking of entrance fees}

At the time of this study, the entrance fees charged by the WD for non-citizen adults at Selous, Ikorogo, Grumeti and Maswa GRs was USD50, plus an additional USD15 conservation fee for tourists staying outside the reserves. For tourists staying inside the GRs, the entrance fee is the same, but the conservation fee increased to USD25. This is the same entrance fee charged by TANAPA for the Serengeti. By contrast, the entrance fees charged in WMAs are the lowest in the country, at USD10 for adults (see Table 1). Entrance fees are valid for $24 \mathrm{~h}$ in the WD and TANAPA's PAs, and TANAPA's and the NCAA fees are valid for a single entry.

Comparison with entrance fees charged for GRs and WMAs with PAs in other southern African countries demonstrates that entrance fees vary both in price and also the way in which they are charged. Variations include charging a flat fee for the entrance and activities, to different rates depending on where the visitor is domiciled, to a fee that depends on the means of travel. Table 2 shows that the value of entrance fees charged for non-citizen adults at GRs are the second highest in the region, surpassed only by Kenya's national parks, at USD80. The non-citizen adult entrance fee for WMAs is the same as the cheapest national park in Zimbabwe and more than the fee for adult non-citizens in Namibia (Table 3).
All but one of the park agencies reviewed charged different entrance fees for different reserves, while Botswana charges the same entrance fee for all PAs.

The fee categories relating to origin used by the WD are the same as applied by TANAPA and the NCAA (i.e. adult, child, citizen, non-citizen). However, while TAWA's citizen prices apply to citizens of Tanzania, TANAPA's citizen rates are applied more broadly, to East African expatriates and residents. Similar categorisations are used by other PA authorities in East and Southern Africa:

- South African National Parks (SANParks) uses rates for their citizens and residents, Southern African Development Community (SADC) nationals and other nationalities.

- KwaZulu-Natal (KZN) Wildlife in South Africa has rates for South African and SADC residents.

- Kenya Wildlife Service charges the same rates for citizens of Kenya, Uganda, Tanzania, Rwanda and Burundi and higher rates for residents and non-citizens.

- Botswana has rates for citizens of Botswana, residents of Botswana and non-residents.

- Namibia has categories for citizen and residents, SADC residents and foreign residents.

- Cape Nature in South Africa does not have different rates for people of different origins. Instead, they have higher 'peak period' rates and lower rates for 'off-peak' times.

TABLE 1: Entrance fees charged by different protected areas in Tanzania (USD Equivalent).

\begin{tabular}{|c|c|c|c|c|c|c|c|c|c|c|}
\hline \multirow[t]{3}{*}{ Category } & \multicolumn{3}{|c|}{ Wildlife Division/ Tanzanian Wildlife Management Authority } & \multirow{2}{*}{\multicolumn{6}{|c|}{ Tanzanian National Park Fees - National Parks }} & \multirow{3}{*}{$\begin{array}{c}\text { Ngorongoro } \\
\text { Conservation } \\
\text { Area Authority- } \\
\text { NC, NG }\end{array}$} \\
\hline & \multicolumn{2}{|c|}{ Game Reserves } & \multirow{2}{*}{$\begin{array}{l}\text { Wildlife Management } \\
\text { Area - All }\end{array}$} & & & & & & & \\
\hline & S, I, G, M & Other reserves & & Ser & Kil & $\mathrm{Ar}, \mathrm{Ta}, \mathrm{Man}$ & Kat & Gomb & Mah & \\
\hline Non-citizen adult & 50 & 30 & 10 & 50 & 70 & 45 & 30 & 100 & 80 & 60 \\
\hline Non-citizen child & 30 & 15 & 5 & 30 & 20 & 15 & 10 & 20 & 20 & 20 \\
\hline Citizen adult & 3 & 1 & 1 & 30 & 35 & 23 & 15 & 50 & 40 & 7 \\
\hline Citizen child & 2 & 1 & 0 & 10 & 10 & 8 & 5 & 10 & 10 & - \\
\hline
\end{tabular}

Source: URoT, 2008; TANAPA, undated; NCAA, 2013; Wikitravel, 2015; Imagine Tanzania Tourism Bureau, 2014; USD1 to TSZ 2176.42: 22 Oct 2015, Oanda.com. Figures rounded to the nearest USD 1

S, Selous; I, Ikogoro; G, Grumeti; M, Maswa; Ser, Serengeti; Kil, Kilimanjaro; Ar, Arusha; Ta, Tarangire; Man, Lake Manyara; Kat, Katavi, Mikumi, Ruaha, Rubondo, Saadani, Kitulo, Mkomazi and Udzungwa; Gomb, Gombe; Mah, Mahale; NC, Ngorongoro Crater.

TABLE 2: Entrance fees charged by different protected areas in Africa (USD Equivalent).

\begin{tabular}{|c|c|c|c|c|c|c|c|c|c|c|c|c|c|c|}
\hline \multirow[t]{3}{*}{ Category } & \multicolumn{6}{|c|}{ South Africa } & \multirow{2}{*}{\multicolumn{2}{|c|}{$\begin{array}{c}\text { Kenya } \\
\text { (National Parks) }\end{array}$}} & \multirow{2}{*}{\multicolumn{2}{|c|}{$\begin{array}{c}\text { Botswana } \\
\text { (National Parks) }\end{array}$}} & \multirow{2}{*}{\multicolumn{2}{|c|}{$\begin{array}{c}\text { Namibia } \\
\text { (National Parks) }\end{array}$}} & \multirow{2}{*}{\multicolumn{2}{|c|}{$\begin{array}{c}\text { Zimbabwe } \\
\text { (National Parks) }\end{array}$}} \\
\hline & \multicolumn{2}{|c|}{ National Parks } & \multicolumn{2}{|c|}{$\begin{array}{l}\text { KwaZulu-Natal } \\
\text { Reserves }\end{array}$} & \multicolumn{2}{|c|}{ Cape Nature } & & & & & & & & \\
\hline & $\mathbf{H}$ & $\mathbf{L}$ & $\mathbf{H}$ & $\mathbf{L}$ & $\mathbf{H}$ & $\mathbf{L}$ & $\mathbf{H}$ & $\mathbf{L}$ & $\mathbf{H}$ & $\mathbf{L}$ & $\mathbf{H}$ & $\mathbf{L}$ & $\mathbf{H}$ & $\mathbf{L}$ \\
\hline Non-citizen adult (international) & 21 & 1 & 14 & 1 & - & - & 80 & 50 & 12 & - & 6 & 3 & 30 & 10 \\
\hline Non-citizen child (international) & 10 & 1 & 7 & 1 & - & - & 20 & 15 & 6 & - & 0 & 0 & 15 & 5 \\
\hline Regional citizen adult & 10 & 1 & 7 & 1 & - & - & 10 & 2 & - & - & 5 & 2 & 20 & 8 \\
\hline Regional citizen child & 5 & 1 & 7 & 1 & - & - & 3 & 2 & - & - & 0 & 0 & 10 & 4 \\
\hline Citizen adult & 5 & 1 & 7 & 1 & - & - & - & - & 1 & - & 2 & 1 & 8 & 3 \\
\hline Citizen child & 3 & 1 & 7 & 1 & - & - & - & - & 1 & - & 0 & 0 & 4 & 2 \\
\hline Resident adult & - & - & - & - & - & - & 12 & 12 & 3 & - & 2 & 1 & - & - \\
\hline Resident child & - & - & - & - & - & - & 6 & 6 & 2 & - & 0 & 0 & - & - \\
\hline Off peak & - & - & - & - & 5 & 2 & - & - & - & - & - & - & - & - \\
\hline Peak & - & - & - & - & 2 & 1 & - & - & - & - & - & - & - & - \\
\hline $\begin{array}{l}\text { Non-resident adult - tour } \\
\text { operator client }\end{array}$ & - & - & - & - & - & - & - & - & 7 & - & - & - & - & - \\
\hline
\end{tabular}

operator client

Source: SANParks 2015; KZN Wildlife 2014; Cape Nature 2013; Kenya Wildlife Service undated, DWNP Botswana, Undated, NWR, 1998-2015; Government of Zimbabwe 2014

$\mathrm{H}$, Highest price charged; L, Lowest price charged. Figures rounded to the nearest USD 1.

Exchange rates from Oanda.com on 22 October 2015: USD, ZAR 13.3854; KSH 100.384; BWP 10.179; NAD 13.385. Zimbabwe uses the USD. 
TABLE 3: Current and proposed entrance fees for Game Reserves and Wildlife Management Areas in USD equivalent values.

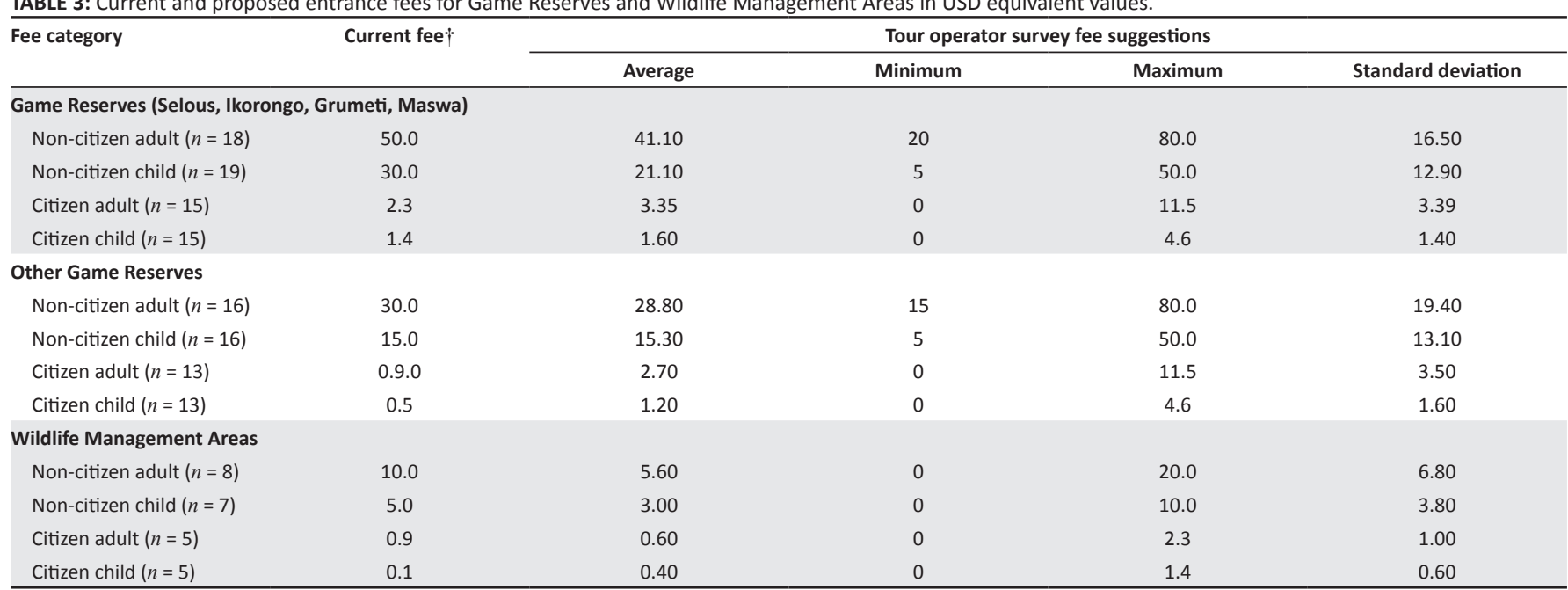

$n$, number of respondents to the specific question, out of a sample of 50 .

$\dagger$, USD1 to TSZ 2176.42: 22 October 2015, Oanda.com. Figures rounded to the nearest USD 0.1.

The WD and NCAA charge adult rates for people aged 18 years and over, while TANAPA charges adult fees for people aged 16 years and over. The WD's children's category is from 5 to 17 years, while TANAPA's are from 5 to 16 years. In all cases, infants below the age of 5 years are free of charge. The categories used for different age classes in other countries in East and Southern Africa vary as to whether adult rate are charged from 12 years (SANParks), 13 years (KZN Wildlife, Cape Nature, Zimbabwe), 16 years (Namibia) or 18 years (Kenya, Botswana).

\section{Consultation process feedback on changes to existing fees}

From the online survey, on average, those proposing a change in fees in Selous, Ikorogno, Grumeti and Maswa GRs suggested a decrease in the rates for non-citizen adults (to USD41) and children (to USD21) compared to a slight increase for citizen adults (USD2.3) and children (to USD1.6). For other GRs, the average suggested fees were not very different from the current fees. In WMAs, the average entrance fee proposed was roughly half the current rate charged for non-citizens. However, in most cases, responses implied that respondents were satisfied with the existing fee (i.e. an alternative value was not suggested).

Further suggestions from stakeholders from the semistructured interviews and online survey in relation to entrance fees included suggestions to:

- Establish an all-inclusive entrance fee that covers entry and all activities (e.g. game drives, walking, camping, night drives) to make them better value for money. A single fee is also much easier to implement and monitor than multiple fees, particularly where there are few field personnel to check permits.

- Standardise fees with TANAPA, including discounted rates for East African residents, with Tanzanian residents paying the same as citizens.

- Explore options for seasonal rates, with discounted rates for low season periods and higher rates for peak times to maximise revenue and encourage more visitation in quite periods.

- Maintain entrance fees as valid for $24 \mathrm{~h}$, but with the option for multiple entries during that time. This provides greater flexibility and value for money for visitors.

- Make the fees in GRs more competitive. The GRs are currently very expensive (e.g. particularly Selous, with an additional conservation fee) given the lack of infrastructure, poaching levels, weak services in Selous and lower prices in competing destinations in Tanzania's national parks, the Ngorongoro Crater and also in PAs across southern Africa.

- Many WMAs have degraded wildlife environments and cannot compete with national parks. They should have a single conservation fees to cover the entrance fee and activities undertaken in the areas.

\section{Discussion}

The study found that current non-citizen adult entrance fees are USD30 - USD50 in GRs and USD10 in WMAs (excluding conservation fees). The assessment identified that GR entrance fees are high when compared to those charged in TANAPA and the Ngorongoro Crater. Furthermore, when compared with entrance fees in other East and Southern African countries, the GR entrance fees are second highest in the region and are exceeded only by Kenya's entrance fee of USD80 per day. Even the entrance fees for WMAs, which have few tourism assets and services, are more expensive than some national parks in Namibia and Zimbabwe. As a number of GRs and WMAs are a greater distance from popular tourism routes, any increase in entrance fees may act as a negative incentive as travel costs are already relatively higher than other Tanzanian wildlife destinations.

The categories of entrance fees applied by the WD, TANAPA and NCAA are different. They each have different age categories for adult, child and infant entrances and have different ways of charging for citizens, residents and nonresidents (e.g. TANAPA has a rate for East African residents), 
which creates a complicated overall picture and adds complexity to the revenue collection and reporting system. In destinations where there are clusters of PAs operated by different PA authorities and villages, tourists may be charged multiple entrance fees on the same days. This escalates the cost for tourists who wish to explore natural and cultural attractions in a particular area and constrains their movement. There are no discounted rates or loyalty cards available for multiple entries to the GRs and WMAs over longer periods of time (e.g. weekly, monthly or annual passes), as there are in other African countries. For example, in South Africa, SANParks has an annual 'Wild Card' fee for individuals, couples and families, with different rates for different 'clusters' of PAs and for citizens or residents, residents of the SADC and international visitors. Similarly, Kenya Wildlife Service has annual passes for adults and children, marine annual passes, tour driver and corporate passes. To illustrate the benefit of the loyalty cards, SANParks generated USD5.4 million in revenue from its Wild Card in the Financial Year Ending March 2015 (SANParks annual report, 2014/2015).

An important element to review in relation to user fees is value for money. In comparing the quality of the tourism experience in GRs and WMAs with national parks in the country or the Ngorongoro Crater, some of the disadvantages identified by stakeholders include that they tend to have less wildlife, are often remote and more difficult to access, have weaker supporting infrastructure, and have fewer, lower capacity employees. However, advantages of GRs and WMAs include that they have more flexibility in terms of the type of tourism activities they can offer (e.g. night drives), low tourist numbers and also that they provide the only opportunity for expansion of accommodation within PAs in Tanzania, as the national parks and Crater are at capacity. Anecdotally, the only GR that was highlighted by stakeholders as having the potential to generate equivalent revenues to a national park was the Selous (however, this could not be confirmed, because revenues for specific PAs were not available).

One of the key challenges faced in this analysis was that it was not possible to establish how much additional revenue fee changes would generate for TAWA because data on existing levels of visitation and tourism revenue were not available. Furthermore, data on associated management costs for each GR and WMA were not available to establish the extent to which existing or proposed revenues would meet them. These data challenges are not unique to Tanzania and have also been described for conservation areas in Mozambique (Rylance 2017).

Before making policy decisions to adjust entrance fees in GRs and WMAs in Tanzania, it is recommended that further research be undertaken. This should include (1) a comprehensive WTP study for an all-inclusive entrance fee to cover entry and all activities, (2) collaborate with TANAPA and NCAA to design and establish single destination-based entrance fees for clusters of PAs and consistent age fee categories for adults, children and infants, (3) research the viability of a loyalty card for multiple entries over longer periods of time (e.g. a 1-2 week pass for international arrivals and monthly or annual passes for citizens and residents), (4) extend the citizen rate to citizens of the East African Community (as done in Kenya and by TANAPA) and establish a discounted rate for residents of Tanzania, (5) fees should be reviewed every 2 years and informed by market research with tourists and operators (including WTP studies and regional benchmarking on PA fees). Because the facilities and wildlife within GRs and WMAs are not as attractive to visitors as in national parks and the Ngorongoro Crater, it is unlikely that moderate changes to the prices of entrance fees for GRs and WMAs would affect visitation to national parks and the Crater.

\section{Conclusion}

At this stage, it should be recognised that the acceptance and effects of fees may depend on the historical, political, legal, economic and social context - including the control and use of funds raised (Buckley 2003). For example, research has found that tourists are willing to pay more for park entrances if that money is used to protect the environment (Baral et al. 2008). There are also differences in the types of services that people are willing to pay for, or not. To illustrate, Bowker, Cordell and Johnson (1999) found that $80 \%$ of visitors surveyed in the United States felt that user fees should be charged to cover at least part of the cost of camping areas, exhibits and boat jetties, but not for picnic areas, historic sites or ablution facilities. Our study found that tourism operators were particularly resistant to increases in entrance fees because there was no transparency about the re-investment of existing fees in the parks. It is clear that any decision to adjust fees should be mindful of the implications for tourists and tour operators. On a practical note, tour operators should be advised of future fee changes 2 years in advance, to ensure that they have time to integrate changes into their brochures and travel budgets. It should also be noted that since the benchmarking analysis and survey took place, a Value Added Tax of $18 \%$ has been introduced on entrance fees in Tanzania. Therefore, the charge for the entrance fee and conservation fee for GRs has increased to USD76.70 and USD88.50 for a tourist staying outside and inside the GR, respectively. As yet, there is no information on how the market will react to this change, particularly in terms of the price competitiveness with other destinations.

Lindberg (2001) suggests that if a decision is made to adjust fees following a review of the advantages and disadvantages, fee objectives should be reviewed to determine the fee amount and type. The following potential fee objectives should be considered (Lindberg 2001:1-2):

- Cost recovery, which involves generation of sufficient revenue to cover part or all of tourism's financial costs (e.g. construction and maintenance of a visitor centre) and possibly tourism's other costs (e.g. ecological damage).

- Generation of 'profit', with the excess of revenue over cost being used to finance traditional conservation 
activities (at the destination or at other sites) or to achieve other objectives.

- Generation of local business opportunities, which may involve low fees in an effort to maximise the number of visitors and/or the earmarking of fees to enhance site or experience quality.

- Provision of maximum opportunities for learning and appreciation of the natural resource, which may also involve low fees.

- Visitor management to reduce congestion and/or ecological damage, which would involve fees high enough to influence visitor behaviour.

At the time of writing, this type of review of user fee objectives has not been undertaken in Tanzania. The adjustment of fees has been primarily based on the objective of raising revenues to pay for management costs. Therefore, this analysis should be used as part of the decision-making process for fee adjustments for the new TAWA, but not in isolation from other important data and comprehensive consultative processes.

\section{Acknowledgements Competing interests}

The authors declare that they have no financial or personal relationships that may have inappropriately influenced them in writing this article.

\section{Authors' contributions}

A.S. worked on the research design; undertook the field research, benchmarking research, stakeholder interviews, and analysis; and wrote part of the literature review, discussion and conclusions. A.R. contributed to the research design, literature review, conclusions and discussion. S.L.L. was involved in the assignment design and some stakeholder interviews.

\section{References}

Asafu-Adjaye, J. \& Tapsuwan, S., 2008, 'A contingent valuation study of scuba diving benefits: Case study in Mu Ko Similan Marine National Park, Thailand', Tourism Management 29(6), 1122-1130. https://doi.org/10.1016/j.tourman. 2008.02.005

Baral, N., Stern, M.J. \& Bhattarai, R., 2008, 'Contingent valuation of ecotourism in Annapurna conservation area, Nepal: Implications for sustainable park finance and local development', Ecological Economics 66(2-3), 218-227. https://doi. org/10.1016/j.ecolecon.2008.02.004

Barnes, J.J., Schier, C. \& Van Rooy, G., 1997, Tourists' willingness to pay for wildlife viewing and wildlife conservation in Namibia, DEA Research Discussion Paper, No. 15, March 1997, Government of Namibia, Windhoek.

Bowker, J.M., Cordell, H.K. \& Johnson, C.Y., 1999, 'User fees for recreation services on public lands: A national assessment', Journal of Park and Recreation Administration 17(3), 1-14

Bruner, A., Kessey, B., Mnaya, J., Wakibara, J. \& Maldonado, J., 2015, Tourists willingness to pay to visit Tanzania's National Parks: A contingent valuation study, Conservation Strategy Fund Discussion Paper No. 9, September 2015 Conservation Strategy Fund, Washington, DC.

Buckley, R., 2003, 'Pay to play in parks: An Australian policy perspective on visito fees in public Pas', Journal of Sustainable Tourism 11(1), 56-73. https://doi. org/10.1080/09669580308667193

Cape Nature, 2013, 'Tariffs', viewed 10 November 2016, from http://www.capenature. co.za/tariffs/

Chase, L.C., Lee, D.R., Schultze, W.D. \& Anderson, D.J., 1998, 'Ecotourism demand and differential pricing of national park access in Costa Rica', Land Economics 74(4), 466-482. https://doi.org/10.2307/3146879
Chen, W., Hong, H., Liu, Y., Zhang, L., Hou, X. \& Raymond, M., 2004, 'Recreation demand and economic value: An application of travel cost method for Xiamen Island', China Economic Review 15(4), 398-406. https://doi.org/10.1016/j. Island, China Econ
chieco.2003.11.001

CPI, undated, 'CPI inflation calculator', viewed 10 November 2016, from http://data. bls.gov/cgi-bin/cpicalc.pl?cost1=1\&year1=2008\&year2=2015

Department of Wildlife and National Parks, Botswana (DWNP Botswana), Undated, 'Park fees', viewed 10 November 2015, from http://www.mewt.gov.bw/DWNP/ article.php?id mnu=214

Dikgang, J. \& Muchapondwa, E., 2016, 'The determination of park fees in support of benefit sharing in Southern Africa', Tourism Economics. https://doi.org/ $10.1177 / 1354816616655254$

Flemming, C.M. \& Cook, A., 2008, 'The recreational value of Lake McKenzie, Fraser Island: An application of the travel cost method', Tourism Management 29(6), 1197-1205. https://doi.org/10.1016/j.tourman.2008.02.022

Government of Zimbabwe, 2014, Parks and Wildlife Management Authority (Tariff of fees) Bylaws, 2014, CAP, Harare, p. 201.

Greiner, R. \& Rolfe, J., 2004, 'Estimating consumer surplus and elasticity of demand of tourist visitation to a region in north Queensland using contingent valuation', tourist visitation to a region in north Queensland using contingent valuation',
Tourism Economics: The Business and Finance of Tourism and Recreation 10(3), 317-328. https://doi.org/10.5367/0000000041895076

Herath, G. \& Kennedy, J., 2004, 'Estimating the economic value of Mount Buffalo National Park with the travel cost and contingent valuation models', Tourism Economics 10(1), 63-78. https://doi.org/10.5367/000000004773166529

Imagine Tanzania Tourism Bureau, 2014, New park fees in the Ngorongoro Conservation Area, viewed 13 August 2014, from https://www.facebook.com/ ittbtz/posts/758013970930170

Kahn, H., 2009, 'Willingness to pay and demand elasticities for two national parks: Empirical evidence from two surveys in Pakistan', Environment, Development and Sustainability 11(2), 293-305. https://doi.org/10.1007/s10668-007-9111-6

Kenya Wildlife Service, undated, Conservation fees from 1st January 2015, Kenya Wildlife Service, Nairobi.

Kibira, G., 2014, 'The economic implications of conservation in Serengeti National Park on adjacent local communities in Tanzania', PhD progress report, School of Economics, University of Cape Town

Krug, W., Suich, H. \& Haimbodi, N., 2002, Park pricing and economic efficiency in Namibia, DEA Research Discussion Paper, no. 45, June 2002, Government of Namibia, Windhoek.

KZN Wildlife, 2014, Important information (Tariffs 2014-15), KZN Wildlife, Pietermaritzburg.

Lindberg, K., 2001, PA visitor fees, overview, Cooperative Research Centre for Sustainable Tourism, Griffith University, Nathan, Australia.

Mmopwlwa, G., Kgathi, D.L. \& Molefhe, L., 2007, 'Tourists' perceptions and their willingness to pay for park fees: A case study of self-drive tourists and clients for mobile tour operators in Moremi GR, Botswana', Tourism Management 28(4), 1044-1056. https://doi.org/10.1016/j.tourman.2006.08.014

Moran, D., 1994, 'Contingent valuation and biodiversity: Measuring the user surplus of Kenyan PAs', Biodiversity \& Conservation 3(8), 663-684. https://doi.org/ 10.1007/BF00126859

Namibia Wildlife Resorts Ltd (NWR) 1998-2015, 'Namibian parks' daily fees', viewed 10 November 2015, from http://www.namibweb.com/nwrdailyfees.htm

Ngorongoro Conservation Area Authority (NCAA), 2013, Rules and regulations, Ngorongoro Conservation Area, viewed 20 November 2015, from http://www. ngorongorocrater.go.tz/index.php/2012-09-05-18-04-07

Reyisdottir, M., Song, H. \& Agrusa, J., 2008, 'Willingness to pay entrance fees to natural attractions: An Icelandic case study', Tourism Management 29(6), 1076-1083. https://doi.org/10.1016/j.tourman.2008.02.016

Richer, J.R. \& Christensen, N.A., 1999, 'Appropriate fees for wilderness day use: Pricing decisions for recreation on public land', Journal of Leisure Research 31(3), 269-280.

Rylance, A., 2017, 'Estimating tourism's contribution to conservation area financing in Mozambique', Tourism and Hospitality Research 17(1), 24-33. https://doi. org/10.1177/1467358415613119

Sanches-Pereira, A. \& Muwanga, M.K., 2015, Enhancing linkages between tourism and sustainable agriculture sectors in the United Republic of Tanzania, United Nations Conference on Trade and Development (UNCTAD), Geneva, Switzerland.

Schultz, S., Pinazzo, J. \& Cifuentes, M., 1998, 'Opportunities and limitations of contingent valuation surveys to determine national park entrance fees: Evidence from Costa Rica', Environment and Development Economics 3, 131-149. https:// doi.org/10.1017/S1355770X98000072

South African National Parks (SANParks), 2015a, 'Conservation fees, 1 November 2015 to 31 October 2016', viewed 10 November 2015, from http://www.sanparks. org/tourism/tariffs/

South African National Parks (SANParks), 2015b, 'Tariffs, 1 November 2015 to 31 October 2016', viewed 10 November 2015, from http://www.sanparks.org/ tourism/tariffs/

Spenceley, A., 2004, 'Responsible nature-based tourism planning in South Africa and the commercialisation of Kruger National Park', in D. Diamantis (ed.), Ecotourism: Management and assessment, pp. 267-280, Thomson Learning, London.

Spenceley, A., 2016, Assessment of the development of non-consumptive tourism activities under Tanzania Wildlife Management Authority (TAWA), Report to GIZ: Part 0: Executive summary, Part 1: Background and context, Part 2: Results and analysis. GIZ, Dar es Salaam, Tanzania. 
Tanzania National Parks (TANAPA), undated, 'Tariffs: July 2015 - June 2016', viewed 10 November 2015, from http://www.tanzaniaparks.com/regulations_and_park fees.html

The United Republic of Tanzania, 2008, The Wildlife Conservation (non-consumptive wildlife utilization) Regulations, 2008, [G.N No. 357 of 28/11/2008]. Government of Tanzania, Dar es Salaam, Tanzania.

Thur, S.M., 2010, 'User fees as sustainable financing mechanisms for marine PAs: An application to the Bonaire National Marine Park', Marine Policy 34(1), 63-69. https://doi.org/10.1016/j.marpol.2009.04.008

Turpie, J. \& Joubert, A., 2001, 'Estimating potential impacts of a change in river quality on the tourism value of Kruger National Park: An application of travel cost contingent, and conjoint valuation methods', Water SA 27(3), 387-398. https:// doi.org/10.4314/wsa.v27i3.4983

United Republic of Tanzania Ministry of Natural Resources and Tourism (MNRT), 2015 Tanzania Wildlife Management Authority (TAWA) Financing plan 2015-2020. MNRT, Dar es Salaam, Tanzania.
United Republic of Tanzania Ministry of Natural Resources and Tourism (MNRT), Tourism Division, 2015, The 2014 Tourism Statistical Bulletin, Draft. MNRT, Dar es Salaam, Tanzania.

Van Sickel, K. \& Eagles, P., 1998, 'Budgets, pricing policies and user fees in Canadian parks' tourism', Tourism Management 19(3), 225-235. https://doi.org/10.1016/ S0261-5177(98)00017-X

Walpole, M., Goodwin, H.J. \& Ward, K.G.R., 2001, 'Pricing policy for tourism in PAs: Lessons from Komodo National Park, Indonesia', Conservation Biology 15(1), 218-227. https://doi.org/10.1111/j.1523-1739.2001.99231.x

Wang, P. \& Jia, J., 2012, 'Tourists willingness to pay for biodiversity conservation and environment protection Dalai Lake protected area: Implications for entrance fee and sustainable management', Ocean and Coastal Management 62, 24-33. https://doi.org/10.1016/j.ocecoaman.2012.03.001

Wikitravel, 2015, 'Ngorongoro Conservation Area', viewed 10 November 2015, from http://wikitravel.org/en/Ngorongoro_Conservation_Area

World Bank, 2015, Tanzania's tourism futures: Harnessing natural assets, World Bank Group report number 96150-TZ, September 2015. World Bank Group, Washington, DC. 